\title{
Natural fluctuations in a stream dwelling newt as a result of extreme rainfall: a 21-year survey of a Calotriton asper population
}

\author{
Albert Montori", Alex Richter-Boix, Marc Franch, Xavier Santos, Núria Garriga, Gustavo A. Llorente \\ Departament de Biologia Animal (Vertebrats), Facultat de Biologia, Universitat de Barcelona, Barcelona, Spain. \\ * Correspondence: Departament de Biologia Animal (Vertebrats), Facultat de Biologia, Universitat de Barcelona, Avinguda Diagonal \\ 645, 08028 Barcelona, Spain. Phone: +34 93402 1456, Fax: +34 93403 5740, E-mail: amontori@ub.edu
}

Received: 23 January 2012; received in revised form: 18 July 2012; accepted: 20 July 2012.

Amphibians living in streams are often subjected to spates. These waterfloods are the main cause of organism drift and mortality, and these effects can be confounded with population decline. Discrimination between population decline and natural fluctuations in unpredictable habitats requires the study of population dynamics through monitoring and long data series. We conducted a 21-year demographic field survey of a newt (Calotriton asper) population in the eastern Pyrenees. Our results indicate that the adult population showed high fluctuations in response to heavy rainfall. Maximal rainfall in $24 \mathrm{~h}$ (higher than $501 / \mathrm{m}^{2}$ ) caused population decreases as a result of catastrophic drift. The larval population also decreased after heavy rainfall. The data from this survey show that the population recovered three years after catastrophic drift. Subadult $C$. asper show terrestrial activity and are not affected by waterfloods. Interannual dynamics revealed that the stock of subadults allowed for rapid population recovery after catastrophic drift episodes. Flooding produced higher mortality when it occurred during winter than during the active cycle of newts. This long-term study provides new insights into the survival strategies displayed by newts in response to extreme stream environments.

Key words: Calotriton; capture-recapture; natural fluctuations; long-term survey; Salamandridae.

Fluctuaciones naturales en un tritón de arroyo como resultado de la lluvia extrema: seguimiento de una población de Calotriton asper durante 21 ańos. Los anfibios que viven en arroyos están sujetos a menudo al impacto de las crecidas. Estas inundaciones son la causa principal de arrastre y muerte de los organismos, pudiendo confundirse estos efectos con declives poblacionales. Discriminar entre declives y fluctuaciones naturales requiere del estudio de las dinámicas poblacionales mediante la monitorización y las series de datos prolongadas. Realizamos un estudio de campo durante 21 ańos de una población del tritón pirenaico (Calotriton asper) en el Pirineo oriental. Nuestros resultados indican que la población de adultos mostró fluctuaciones marcadas como respuesta a las precipitaciones intensas. La precipitación máxima registrada en un periodo de 24 horas (superior a los $501 / \mathrm{m}^{2}$ ) causó un descenso de la población como consecuencia de una avenida catastrófica. La población de larvas también se redujo tras las lluvias intensas. Los datos del presente estudio muestran que la población se recuperó tres años después de la catástrofe. Los subadultos de C. asper presentan actividad terrestre y no se ven afectados por las inundaciones. Las dinámicas interanuales revelaron que la reserva de subadultos permitió la rápida recuperación de la población tras las crecidas catastróficas. Las inundaciones causaron más muertes cuando sucedieron en invierno que cuando lo hicieron durante el periodo de actividad de los tritones. Este estudio a largo plazo ayuda a comprender las estrategias de supervivencia que presentan los tritones en respuesta a ambientes extremos.

Key words: Calotriton; captura-recaptura; fluctuaciones naturales; Salamandridae; seguimiento a largo plazo. 
Organisms inhabiting running waters are frequently exposed to strong changes in hydrological conditions (RESH et al., 1988), downstream drift being one of the most important factors modifying their population structure (LANCASTER et al., 1990; LANCASTER \& HILDREW, 1993) and a major cause of individual mortality (THIESMEIER $\&$ SCHUHMACHER, 1990; BARRETT et al., 2010). These catastrophic perturbations are expected to produce high mortality rates in natural populations; however, many species and communities living in these habitats seek shelter in benthic refuges, such as stones, debris dams, woody debris or fissures in the rocky riverbed, and thus typically recover quickly from strong hydraulic discharge (BILby \& LiKENS, 1980; LANCASTER et al., 1990; LANCASTER \& HildreW, 1993). It is expected that organisms from habitats exposed to strong temporal alterations will show high population growth rates and are thus resilient in those constantly altered environments (MAY et al., 1974). The relationship between population growth rate and size is crucial to an understanding of population dynamics and the speed at which populations return to equilibrium (near population carrying capacity) after displacement by an external perturbation (MAY et al., 1974; SALVIDIO, 2011).

Amphibians living in running waters exposed to strong changes in hydrological conditions are good candidates to examine temporal population trends and how they recover after perturbations. In fact, amphibians exhibit strong year-to-year population fluctuations (PECHMANN et al., 1991). Given the current trend in population decline and species extinction worldwide (BLAUSTEIN et al., 1994; HOULAHAN et al., 2000; STUART et al., 2004; BEEBEE \& GRIFFITHS, 2005), it is sometimes difficult to distinguish population decline from natural fluctuations. Thus deeper knowledge of amphibian demography in natural habitats over time and the analysis of demographic time-series data may allow for detecting true population trends (BLAUSTEIN et al., 1994; REED \& BLAUSTEIN, 1995) and ultimate factors that determine amphibian population dynamics (MEYER et al., 1998). Furthermore, BIEK et al. (2002) consider that inventory and monitoring efforts should be complemented by demographic studies in order to apply quantitative analyses to a wide range of species and life-history groups. Accordingly, long-term demographic monitoring is required to analyze temporal fluctuations and how populations recover after natural perturbations.

We have examined temporal variation in population trends in the Pyrenean newt Calotriton asper, a species highly adapted to running-water habitats. It presents a flattened body, rough skin, lung reduction and horny nails. This newt inhabits clear oxygen-rich mountain streams throughout the Pyrenean Range (MONTORi \& Herrero, 2004), where spates and hydrological fluctuations are common. It is also found in mountain lakes and subterranean water bodies. The habitats occupied by $C$. asper make it vulnerable to water perturbations.

Newt population size was estimated in a Pyrenean stream during a 21-year fieldwork study (from 1982 to 2002). In November 1982, an unusually high rainfall affected the stream and decreased the newt population as a result of drift caused by the spate (MONTORI, 1988; MONTORI et al., 2008). We collected 
demographic data over time to determine the natural dynamics of the population, obtain information on the speed at which the population returns to equilibrium after perturbations, and establish the environmental variables that govern the growth and demographic stochasticity of $C$. asper populations. In summary, this long-term study is aimed to examine how climatic events modify population size and to identify newt recovery strategies in response to catastrophic events.

\section{Materials AND MeTHOdS}

\section{Study area}

The study was carried out since August 1982 till September 2002 in the Pi brook, a stream located in the Cadí range in the Spanish PrePyrenean Mountain Range (Fig. 1). This is one of a series of chains in the Spanish Pre-Pyrenean Mountains that run mostly in parallel to the main Pyrenean axis (Fig. 1). Located in the "Parc Natural del Cadí-Moixeró", the Pi brook ( $42^{\circ} 19^{\prime}$ 43.17" N; $1^{\circ} 45^{\prime} 18.68 " \mathrm{E}$ ) descends through the Pi Valley from 1700 to $1100 \mathrm{~m}$ above sea level, and then reaches the Segre River. The stream has riffles, waterfalls, pools and canyons, and receives little direct sunlight during the day because of its northern orientation and vertical surrounding hillsides. The average stream depth and width are $30 \mathrm{~cm}$ and $2.5 \mathrm{~m}$, respectively. The water temperature varies from $0.2^{\circ} \mathrm{C}$ in January to $15.4^{\circ} \mathrm{C}$ in July. Newts occupy a $4-\mathrm{km}$ stretch of the stream at an altitude between 1150 and $1600 \mathrm{~m}$ (MONTORI, 1988). This torrent is considered a characteristic habitat of the Pyrenean newt (Clergue-Gazeau \& Martinez-RicA, 1978; MONTORI, 1988).

\section{Newt sampling}

Newt sampling was conducted during a 21-year field work (1982-2002, see MONTORI, 1988). Newts were collected by visual observation of active individuals in open water and also by turning rocks.

During the first year (August 1982-August 1983), we estimated population size in a 1500-m stretch of stream using capture-markrecapture techniques. We caught newts along the stretch on a monthly basis over that year.

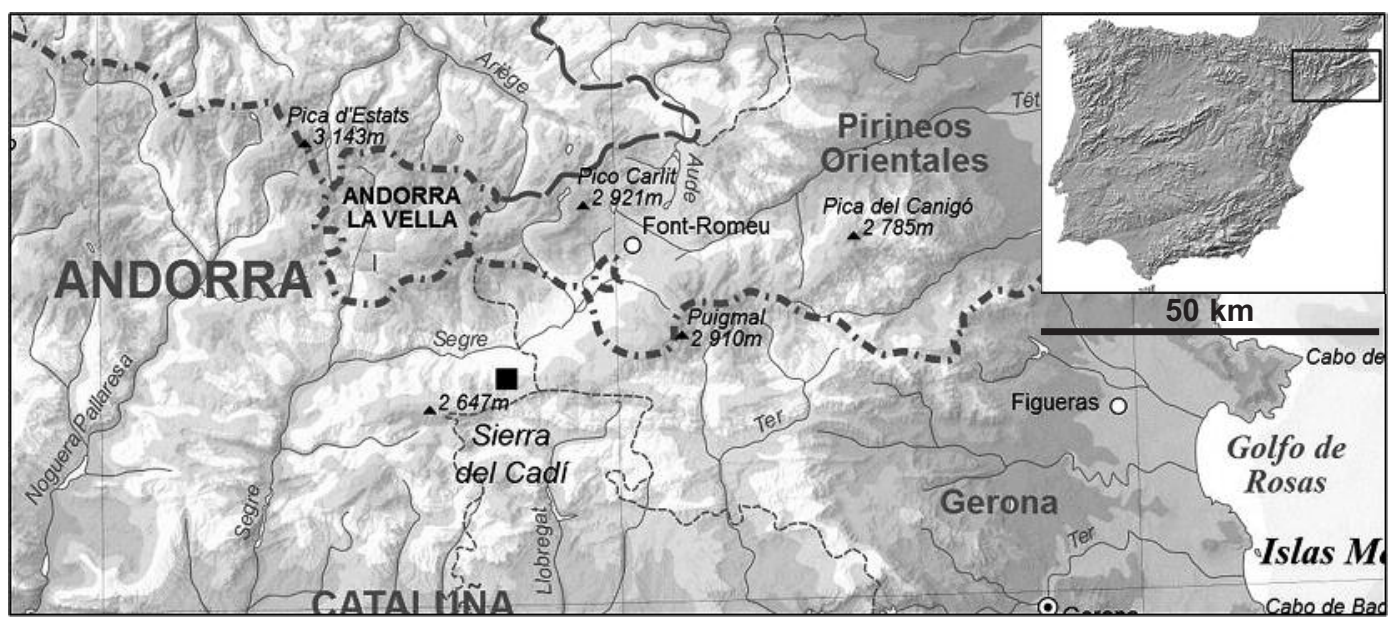

Figure 1: Localization of study stream (Black square). 
This intensive method was used to accurately measure population size of $C$. asper in the study area. To maximize marking efficiency, an intensive initial capture was conducted in August 1982. Each newt was marked by toe clipping. No more than one toe per limb (mostly two or three in total) was clipped. Toeclipping is a standard technique used in amphibian field research. Several studies have found no negative effects of this method (FUNK et al., 2005) and alternative techniques may affect individual survival (e.g. SCHLAEPFER, 1998). MCCARTHY \& PARRIS (2004) demonstrated that individual return rates in several frog species were affected only when more than three toes were clipped. Hence, removing two or three toes does not affect newt viability (MONTORI, 1988; MONTORI et al., 2008). After marking the animals, we released them to the same capture or recapture zone. During that period we used beryllium nitrate $0.05 \mathrm{~N}$ in order to inhibit toe regeneration (MONTORI, 1988). However, we detected the first regeneration episode in the second study year. For this reason, we stopped the capture-mark-recapture method in 1983 and used transect censuses to estimate annual variation in newt population size thereafter to the end of the study in 2002.

From 1983 to 2002 we surveyed a 150 -m stretch within the former $1500-\mathrm{m}$ stretch in order to examine temporal variation in population size over 21 years of fieldwork sampling. This $150-\mathrm{m}$ stretch was subdivided in three 50 -m segments in order to obtain three different population size estimations for the $1500-\mathrm{m}$ stream, allowing this procedure to calculate the standard error of mean. These estimations were calculated by comparing the observed abundance of newts in September 1982 with values obtained for each 50 -m segment sampled from 1983 to 2002. These three 50-m stretches were chosen on the basis of three conditions: 1) the presence of running water throughout the year, 2) high density of newts, and 3) high density of newts in adjacent segments. To compare inter-annual fluctuations, capture effort was constant along years (i.e. two researchers, same start and end time and zone, and similar hydrological and weather conditions). When meteorological or hydrological conditions changed during the sampling, this survey was excluded and sampling was repeated in the following days.

\section{Estimation of annual population size and sta- tistical analyses}

After the first year of capture-mark-recapture fieldwork in August 1982-August 1983, we applied two statistical methods to estimate population size: 1) after the first and second capture-recapture visits in August and September 1982, population size and 95\% confidence interval were estimated by Chapman's modification of the LincolnPetersen method (CHAPMAN, 1951) for closed populations. Given the low mobility of the species (MONTORI et al., 2008) and the short period between the first and second visits (14 days) we assumed that newt population was closed; 2) for the rest of the year up to August 1983 we used the Jolly-Seber method (Jolly, 1965; SEBER, 1965) to estimate monthly variation of the number of newts.

The inter-annual population growth rate $(\mathrm{R})$ was defined as $R=\log _{c}\left(N_{t}\right)-\log _{c}\left(N_{t-1}\right)$, where $\mathrm{N}_{t}$ is the number of individuals at time $t$ (Berryman, 1999; Sibly \& Hone, 2002). This demographic parameter provides insight 
into whether the population remains constant near its carrying capacity $(\mathrm{R}=0)$, increases $(\mathrm{R}>0)$ or decreases $(\mathrm{R}<0)$ in abundance over time (Sibly \& Hone, 2002).

From September 1983 to September 2002, adult newts and larvae were counted during each annual sampling. Inter-annual balance (BPOP) was estimated as the number of adults in year $i$ minus the number of adults in year $i-1$. Mortality was considered higher than recruitment when $\mathrm{BPOP}<0$ (population decreases). This assumption assumes that recruitment was offset by natural and waterflow-related mortality, although it is not possible to discern between the proportion of mortality caused by each factor.

A stepwise multiple regression was used to model which climate variables were the best predictors of the number of adult newts and larvae found per year, as well as the interannual balance of adult population. For these analyses, the numbers of adults and larvae were log-transformed to linearize regressions.

The following meteorological variables were recorded as they were expected to affect stream hydrology and consequently to influence inter-annual $C$. asper population size variation from 1982 to 2002: annual rainfall, daily thermal oscillation, annual snow, number of days with temperature higher than $30^{\circ} \mathrm{C}$, number of days with temperature lower than $-10^{\circ} \mathrm{C}$, number of rainy days, maximal rainfall in $24 \mathrm{~h}$, maximal temperature, minimal temperature, and average temperature. For a census of year $i$, abiotic variables considered for the analysis were those recorded in the previous year $(i-1)$. High scores of the "maximal rainfall in $24 \mathrm{~h}$ " variable were used as indicator of unusual or extreme rainfall and waterflow occurrence.
Autocorrelation function (ACF) was used to evaluate periodicity and a partial rate correlation function (ACFP) to detect the feedback dimension in the time series of number of adult newts from 1982 to 2002, number of larvae and inter-annual balance.

An analysis of the variance (ANOVA) was used to compare the mortality of newts related to biological period in which extreme rainfalls occurred (wintering or activity period) using size population balance as a mortality estimator. Wintering in newts occurred approximately between October $15^{\text {th }}$ and March 15 $5^{\text {th }}$. Analyses were performed with the Statistica software package (StatSoft, Tulsa, Oklahoma, USA).

\section{RESULTS}

\section{First-year sampling (August 1982-August 1983)}

During the first study period, 1476 adults were captured, marked and released at the place of capture, and 251 newts were recaptured (including multiple recaptures of the same individual). In the study stretch $(1.5 \mathrm{~km})$, for the first capture-recapture period (August 1982September 1982) the estimated population size (mean \pm SE) was $4998 \pm 948$ newts as estimated by the Jolly-Seber method, and 3673 newts (95\% confidence interval 3166-4336) as estimated by the Chapman's method (Table 1). Although there was a wide divergence between the two methods, both gave a good indication of the abundance of newts in the stretch sampled.

The unusual rainfall episode in November 1982 (nearly $1551 / \mathrm{m}^{2}$ in one day) produced a severe flood, and the structure of the stream changed drastically, with a dramatic decrease in newt population (Fig. 2). The estimated survival from September 1982 to April 1983 was 0.263. 
Table 1: Population size estimations by means of Jolly-Seber and Chapman's modification of the LincolnPetersen method in the $1.5 \mathrm{~km}$ of brook. $\mathrm{n}_{\mathrm{i}}$ : number of newts captured at time $\mathrm{i}$. $\mathrm{r}_{\mathrm{i}}$ : number of newly marked newts released at time i. $m_{i}$ : number of newts recaptured at time i. $y_{i}$ : number of newts marked at time $i$ and recaptured at time $\mathrm{i}+1 . \mathrm{N}_{\mathrm{i}}$ : estimated adult population size. $\Phi_{\mathrm{i}}$ : survival rate from time $\mathrm{i}-1$ to time $\mathrm{i}$. $\mathrm{B}_{\mathrm{r}}$ : net number of individuals entering the population between samplings. SE: standard error. CI: confidence interval. NC: not calculable because of data structure.

\begin{tabular}{|c|c|c|c|c|c|c|c|c|c|c|c|c|c|c|c|c|}
\hline \multirow[t]{2}{*}{ Date } & \multirow[t]{2}{*}{$\mathrm{n}_{\mathrm{i}}$} & \multirow[t]{2}{*}{$r_{i}$} & \multicolumn{6}{|c|}{ Date of last capture } & \multirow[t]{2}{*}{$\mathrm{m}_{\mathrm{i}}$} & \multirow[t]{2}{*}{$\mathrm{y}_{\mathrm{i}}$} & \multicolumn{3}{|c|}{$\mathrm{N}_{\mathrm{i}}$} & \multicolumn{2}{|c|}{$\Phi_{\mathrm{i}}$} & \multirow[t]{2}{*}{$B_{t}$} \\
\hline & & & $\overline{\text { Aug } 82}$ & Sep 82 & Apr 8 & May 8 & un 83 & $\overline{\text { Jul } 83}$ & & & $\overline{\text { Mean }}$ & SE & $95 \% \mathrm{CI}$ & $\overline{\text { Mean }}$ & SE & \\
\hline Aug 82 & 724 & 724 & & & & & & & & 183 & & & & & & \\
\hline S. Sep 82 & 546 & 438 & 108 & & & & & & 108 & 41 & 4998 & 948 & & 0.263 & 0.069 & 389 \\
\hline Apr 83 & 75 & 59 & 11 & 5 & & & & & 16 & 12 & 1561 & 472 & & 0.754 & 0.206 & -146 \\
\hline 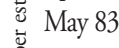 & 88 & 62 & 17 & 5 & 4 & & & & 26 & 9 & 975 & 237 & & 1 & - & 18 \\
\hline อัّ Jun 83 & 80 & 51 & 18 & 7 & 2 & 2 & & & 29 & 7 & 905 & 249 & & 0.923 & 0.301 & 329 \\
\hline Jul 83 & 95 & 67 & 15 & 6 & 3 & 3 & 1 & & 28 & 14 & 1091 & 310 & & $\mathrm{NC}$ & - & $\mathrm{NC}$ \\
\hline Aug 83 & 119 & 75 & 13 & 10 & 6 & 4 & 7 & 4 & 44 & & 2317 & 1327 & & 0.004 & 0.037 & -88 \\
\hline Chapman's & nodifice & ation of & f the Lis & coln-Pet & rsen $\mathrm{m}$ & & & & & & 3673 & & $3166-4336$ & & & \\
\hline
\end{tabular}

After the flood, the number of newts decreased and successive monthly surveys (between March and August) did not show a quick population recovery to the number of newts caught in September 1982 (Table 1), even though the capture effort was constant throughout the study period. From July to August 1983, the number of individuals increased as a result of the incorporation of terrestrial subadults into the torrent upon reaching sexual maturity (immature newts of this species have a terrestrial period until sexual maturity, Fig. 3).

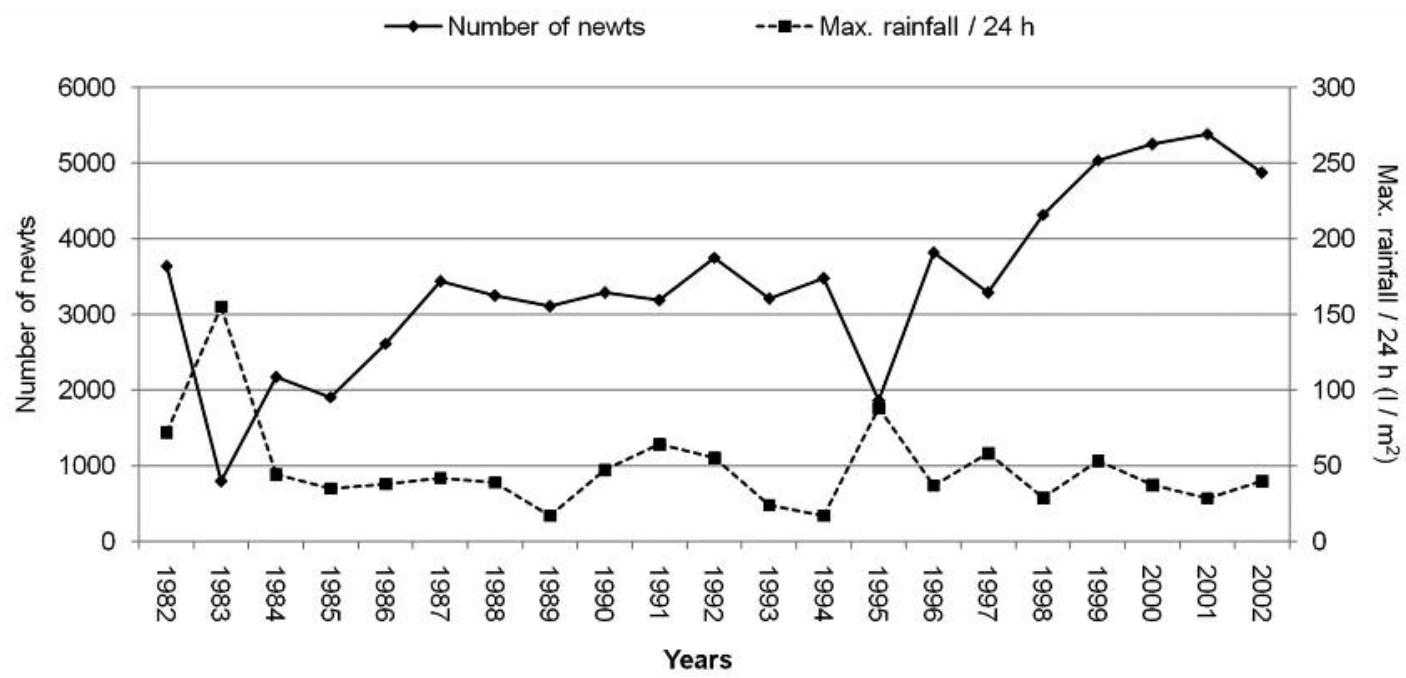

Figure 2: Population size of Calotriton asper at the Pi stream (solid line, rhombuses) estimated by transects from 1982 to 2002 and maximal rainfall in $24 \mathrm{~h}$ (broken line, squares) occurred before the censuses. $\mathrm{R}=-0.539, P<0.01171$, overall standard error of the estimation: 1006.5 . 


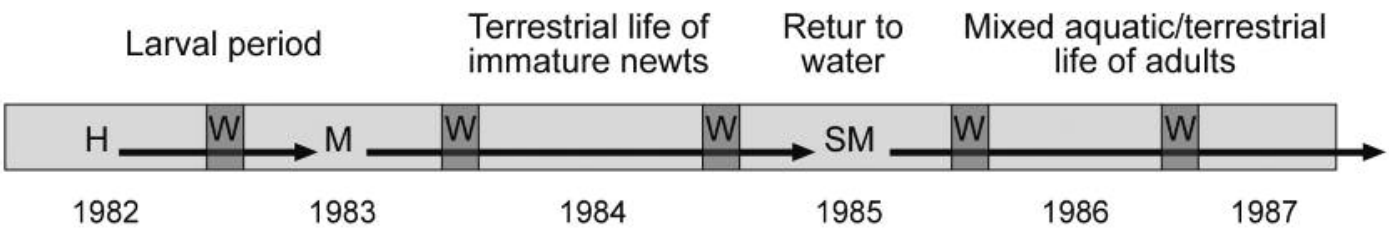

Figure 3: Biological cycle of Calotriton asper at the Pi stream in their first five years of life. H: hatching. W: wintering. M: metamorphosis. SM: sexual maturity.

\section{2-2002 sampling}

The annual surveys from 1982 to 2002 also showed a significant decrease in the number of individuals after the sampling in 1982 as a result of the spate that happened in November 1982 (Table 2). In 1984, the number of newts increased as recently matured newts returned to the aquatic environment (Fig. 3). As in 1982, another episode of extreme rainfall followed by high newt mortality occurred in 1994. After both perturbations, the newt population showed rapid recovery: three years after the 1982 and 1994 floods (Fig. 2). The mean estimated

Table 2: Data used in the study. \%M: percentage of males. LV: number of larvae. NPOP: estimated population size. SE: standard error. BPOP: balance of population size between years. RMAX24: maximal rainfall in $24 \mathrm{~h}\left(1 / \mathrm{m}^{2}\right)$. DTO: daily thermal oscillation $\left({ }^{\circ} \mathrm{C}\right)$. GS: snow grams. NDT+30: number of days with temperatures above $30^{\circ} \mathrm{C}$. NDT-10: number of days with temperatures below $-10^{\circ} \mathrm{C}$. NRD: number of days with rain. RTOT: total annual rainfall $\left(1 / \mathrm{m}^{2}\right)$. TMAX: maximal year temperature $\left({ }^{\circ} \mathrm{C}\right)$. TMIN: minimal year temperature $\left({ }^{\circ} \mathrm{C}\right)$. TAVG: annual average temperature $\left({ }^{\circ} \mathrm{C}\right)$.

\begin{tabular}{rrrrrrrrrrrrrrrrr} 
Year & $\% M$ & LV NPOPa & SE & BPOP RMAX24 & DTO & GS & NDT+30 NDT-10 NRD RTOT TMAX TMIN TAVG \\
\hline 1982 & 43.8 & 1 & 3673 & & & 72.0 & 11 & 251 & 4 & 0 & 140 & 1203 & 32 & -12 & 8.1 \\
1983 & 44.0 & 4 & 793 & 125 & -2844 & 155.0 & 15 & 98 & 2 & 5 & 109 & 766 & 31 & -19 & 9.2 \\
1984 & 50.8 & 3 & 2172 & 341 & 1379 & 44.0 & 9 & 117 & 0 & 0 & 131 & 935 & 29 & -14 & 7.4 \\
1985 & 45.0 & 15 & 1905 & 207 & -266 & 35.0 & 15 & 102 & 0 & 4 & 122 & 766 & 29 & -20 & 8.5 \\
1986 & 38.5 & 26 & 2611 & 210 & 706 & 38.0 & 12 & 154 & 2 & 1 & 139 & 781 & 31 & -16 & 8.4 \\
1987 & 46.9 & 36 & 3437 & 136 & 826 & 42.0 & 14 & 125 & 2 & 4 & 148 & 1100 & 32 & -15 & 8.6 \\
1988 & 55.1 & 11 & 3244 & 129 & -193 & 39.0 & 10 & 119 & 0 & 4 & 146 & 789 & 29 & -17 & 8.5 \\
1989 & 60.6 & 19 & 3104 & 53 & -140 & 17.0 & 6 & 106 & 0 & 0 & 132 & 877 & 30 & -12 & 9.1 \\
1990 & 51.5 & 24 & 3284 & 142 & 180 & 47.0 & 9 & 137 & 0 & 0 & 150 & 1089 & 29 & -15 & 8.8 \\
1991 & 66.4 & 4 & 3184 & 74 & -100 & 64.0 & 10 & 136 & 0 & 0 & 131 & 770 & 30 & -16 & 8.2 \\
1992 & 51.3 & 18 & 3750 & 280 & 566 & 55.0 & 5 & 176 & 0 & 0 & 151 & 1308 & 28 & -11 & 8.2 \\
1993 & 51.0 & 46 & 3204 & 263 & -546 & 24.0 & 11 & 106 & 1 & 0 & 128 & 774 & 31 & -11 & 8.0 \\
1994 & 49.7 & 55 & 3474 & 422 & 270 & 17.0 & 18 & 177 & 1 & 0 & 140 & 1012 & 39 & -14 & 9.5 \\
1995 & 57.3 & 1 & 1866 & 172 & -1608 & 88.0 & 12 & 105 & 1 & 1 & 147 & 951 & 31 & -12 & 8.5 \\
1996 & 56.7 & 7 & 3811 & 684 & 1945 & 37.0 & 12 & 192 & 0 & 2 & 164 & 1373 & 30 & -14 & 7.6 \\
1997 & 51.4 & 20 & 3283 & 215 & -528 & 58.0 & 8 & 131 & 0 & 0 & 147 & 1039 & 29 & -13 & 9.3 \\
1998 & 49.7 & 45 & 4317 & 278 & 1034 & 28.8 & 10 & 105 & 0 & 0 & 127 & 778 & 30 & -12 & 8.8 \\
1999 & 52.5 & 44 & 5036 & 537 & 719 & 53.0 & 11 & 125 & 0 & 6 & 143 & 1105 & 29 & -16 & 8.4 \\
2000 & 54.4 & 60 & 5250 & 324 & 214 & 37.2 & 8 & 62 & 0 & 0 & 140 & 947 & 29 & -14 & 8.9 \\
2001 & 51.5 & 54 & 5385 & 779 & 135 & 28.4 & 10 & 70 & 4 & 5 & 122 & 840 & 32 & -10 & 8.9 \\
2002 & 51.5 & 10 & 4868 & 829 & -517 & 39.8 & 9 & 58 & 1 & 0 & 152 & 822 & 30 & -6 & 8.4 \\
\hline
\end{tabular}

${ }^{\text {a }}$ Estimation of 1982 made by the Chapman's method (see Table 1). Estimations from 1983 to 2002 made by contrast with the 1982 value. 
inter-annual population growth rate $(\mathrm{R})$ calculated after the 21-year surveys was close to zero (0.0063), thereby indicating that the newt population remained near its carrying capacity.

The ACF used to evaluate periodicity and the ACFP did not detect significant periodicity in annual population estimated from the 1982 to 1992 series.

\section{Abiotic factors determining population size}

The explained variances of the stepwise multiple regression analyses were higher than $60 \%$ and showed that the variable "maximal rainfall in $24 \mathrm{~h}$ " was negatively correlated with the three dependent variables: number of adults, number of larvae and inter-annual population balance (Table 3). Besides, a set of climatic variables were included in the final stepwise models as predictors of the three population parameters (see Table 3 for variables included in the final steptwise models). The intercept of the regression between the population balance and the maximal annual rainfall in $24 \mathrm{~h}$ was close to $501 / \mathrm{m}^{2}$ in such period (Fig. 4). We consider that rainfall over this amount may produce a negative population balance. Mortality was higher when extreme rainfall (higher than $501 / \mathrm{m}^{2}$ ) occurred during the wintering period than when it happened during newt activity period (ANOVA: $\mathrm{F}_{1,18}=11.801 ; P=0.0029$ ) (Fig. 5).

Table 3: Multiple regression summary for three dependent variables ( $\log$ of number of adults, Log of number of larvae, inter-annual population balance). Bold values are significant. All variables contributing to increase the $\mathrm{R}^{2}$ of the model are displayed, regardless of their statistical significance. Variable names are summarized in Table 2.

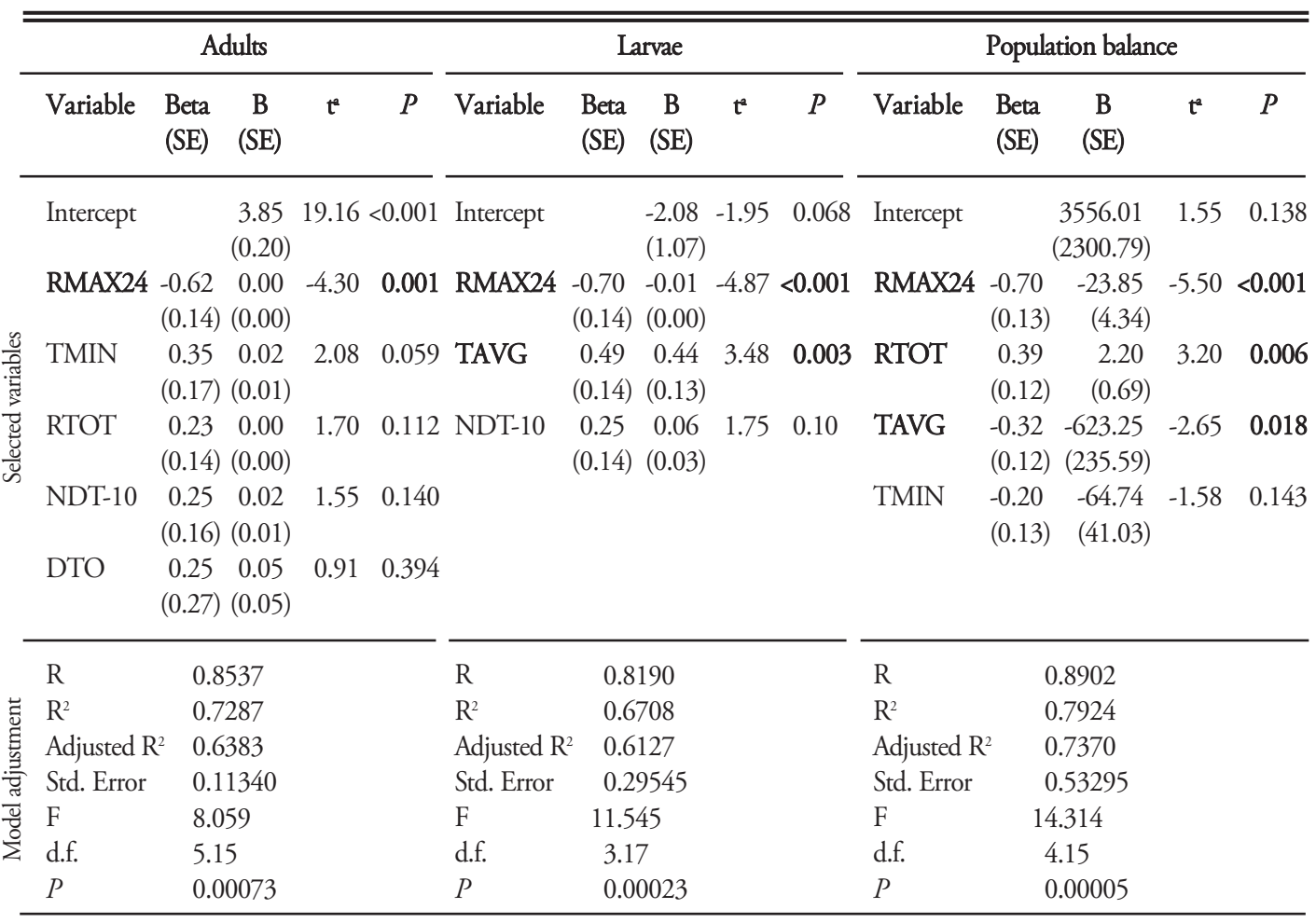

${ }^{a}$ d.f. $=10$ 

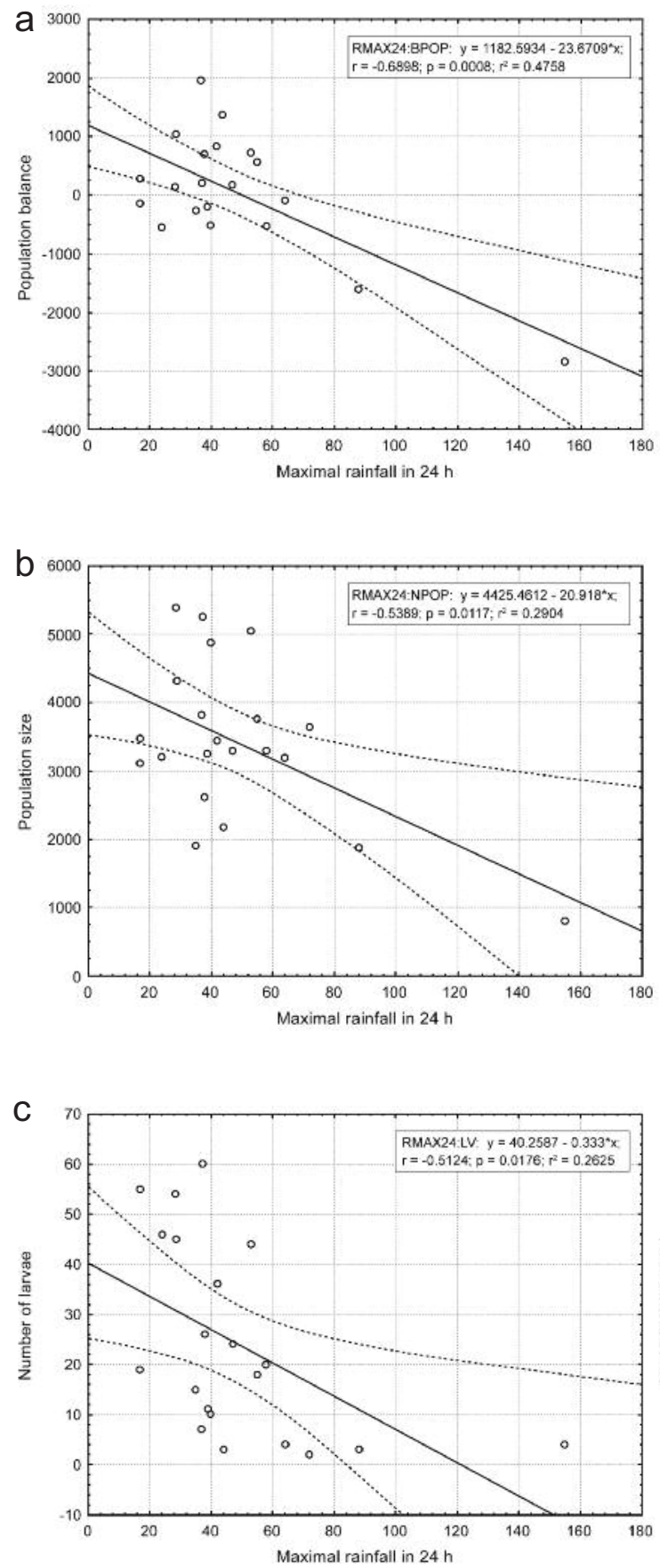

Figure 4: Linear regression adjust ( $\pm 95 \%$ confidence interval) of maximal rainfall in $24 \mathrm{~h}$ with (a) inter-annual population balance, (b) estimated population size, and (c) number of larvae. See table 2 for abbreviators.

\section{DisCUSSION}

The two methods to estimate population size during the first sampling year showed considerable divergence in newt population in September 1982 (4997 and 3673 from Jolly-Seber and Chapman methods, respectively). However, both estimators coincided in indicating the high abundance of newts in the $1.5-\mathrm{km}$ stretch of brook.

Our results indicate that maximal rainfall in $24 \mathrm{~h}$ (over $501 / \mathrm{m}^{2}$ ) is the main factor influencing newt dynamics. Despite this high newt density, periodic floods in the stream due to extreme rainfall produced marked inter-annual fluctuations in population size. The rapid population recovery detected after floods suggests that this species is highly adapted to survive in running-water habitats affected by periodic and severe floods. Demographic effects of extreme rainfall episodes producing catastrophic drift and high population decline, mainly of larvae, has

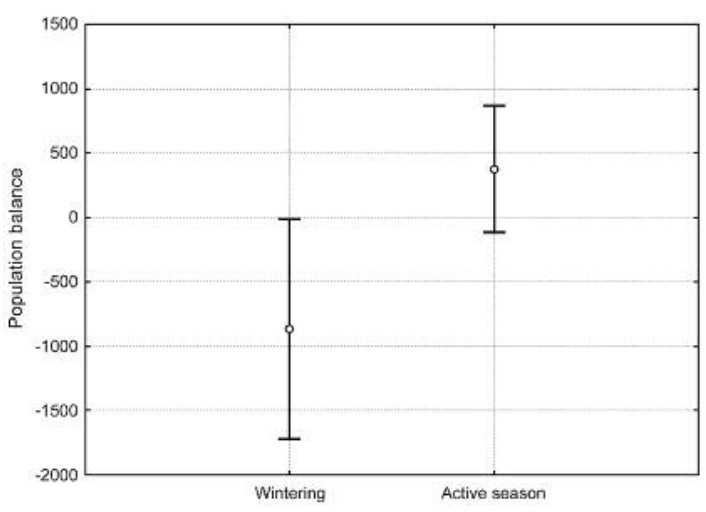

Figure 5: Inter-annual population balance when rainfall occurs during wintering or during the active cycle. Boxes indicate standard error and bars indicate standard deviation of the mean. 
been observed previously (MÜLLER, 1954; Petranka \& Sih, 1986; Barret et al., 2010). For example, Petranka \& SiH (1986) analysed the survival rate of Ambystoma texanum larvae in relation to various biotic and abiotic factors and reported that up to $90 \%$ of young larvae do not survive to periods of high waterflow.

We detected a negative relation between abundance of $C$. asper larvae in the Pi Valley and maximal rainfall in $24 \mathrm{~h}$. These waterflows cause high larval mortality, thereby reducing population recruitment as they determined the number of adult newts present in the stream in subsequent years. Similar findings have been reported by BARRETT et al. (2010) who concluded that the frequency and magnitude of waterflows, which then lead to decreased larval density, were the best descriptors to explain stream salamander decline in urban areas. Moreover, experimental data support that spate frequency (which was highly correlated with spate magnitude) was the best predictor of salamander density across an urban-rural stream gradient (BARRETT, 2009; BARRETT et al., 2010). These examples suggest that salamanders cannot maintain their position in the stream during high flows and that recolonization after subsidence of intensive flows is low. In addition, ThiesmeIER (1992) demonstrated that stream dwelling species like C. asper or the fire salamander Salamandra salamandra drifted less than pond species (e.g. Triturus spp).

THIESMEIER \& SCHUHMACHER (1990) observed a catastrophic drift of larval S. salamandra. Drift of the youngest larvae was determined by the behaviour of spawning females and by stream conditions, whereas the largest larvae drift occured when their retreats became too small to provide an adequate food supply. However, the $C$. asper population is not food-limited in the Pi Valley stream (MONTORI, 1991, 1992). BAumgarTnER $e t$ al., (1999) used field data to argue that larval $S$. salamandra preferred lower current speeds within a given stream, as they found fewer specimens in streams with higher mean stream discharge.

Other authors have documented species that are susceptible to spates; however, those studies were performed largely in the context of hydrological changes that occur with increasing stream order (DUDGEON, 1993; BAUMgartner et al., 1999; LeIPELT, 2005). For example, LEIPELT (2005) used artificial streams to evaluate the response of four species of Odonata to a high-flow stream environment. In that study, the two species most susceptible to drift were found in lower order streams that were less prone to spates. This author interpreted these findings as evidence that hydrological factors shape species distribution and survivorship. Collectively, these studies support the notion that spate frequency and / or magnitude influence the abundance and distribution of stream organisms. Extreme rainfall produces changes in the bed structure and in the bank morphology of streams. However, in a previous study (MONTORI et al., 2008) we demonstrated that the distribution pattern of newts along the stream was not influenced by these structural changes associated with spates.

Thus the question remains as to how $C$. asper maintains or recovers population levels in habitats frequently affected by severe waterfloods. During the 1982-2002 sampling, we recorded two episodes of extreme rainfall, in 
1982 and 1994. After these episodes, increased waterflow produced high mortality; however, the population recovered rapidly, despite being a species with a small clutch size if compared to other European newt species (Clergue-Gazeau, 1971; Montori, 1988, 1992; Montori \& Herrero, 2004). In fact, population quickly recovered values similar to those observed before the flood. This observation is attributed to the fact that subadults are almost exclusively terrestrial until sexual maturity (MONTORI \& Herrero, 2004). Hence, subadult $C$. asper would act as a population stock to facilitate population recovery in a few years after waterfloods. As spates are common in stream environments, this recovery strategy would allow this species to overcome these catastrophic episodes. The findings of our 19822002 sampling are consistent with this explanation: the number of newts severely decreased the first year after each catastrophic drift, whereas in the second year the return of sexually mature subadults produced a parallel increase in the population. The decrease in numbers observed in the third year after the flood can be explained by the absence of recruitment as those larvae that should have reached sexual maturity died during the drift caused by the spate. This pattern was observed in the two occasions when extreme rainfall was registered. The hypothesis of a population recover by means of upstream dispersal can be rejected from the results of a previous study demonstrating that no upstream or downstream movements occur in this population (MONTORI et al., 2008).

These data verify for the first time the relevance of the terrestrial life period of newts for the recovery of populations in unpredicta- ble aquatic environments frequently affected by extreme rainfall. In this regard, it is particularly important to determine whether the increases in extreme rainfall caused by climatic change predicted by some authors (BATES et al., 2008) would produce higher vulnerability and risk of extinction for $C$. asper stream populations. Interestingly, mortality was higher when extreme rainfall occurred during the overwinter period than during the activity period. This result indicates that during the active cycle, $C$. asper has developed behavioural strategies to avoid waterflow drift. In fact, MONTORI (2008) reported that Pyrenean newts predict waterflows, although the exact mechanism by which they do this is unknown. According to the field observations made by Clergue-Gazeau \& MARTÍNEZ-RICA (1978), in running waters, when a spate starts, newts leave refuges and move to banks where water velocity is lower. In periods of high waterflow, there are observations of newts leaving the water (MONTORI, 2008). These behavioural strategies are not displayed in winter as newts are buried in stream banks.

In conclusion, our findings further demonstrate the adaptability of Pyrenean newts to extreme environments, such as mountain streams where climatic conditions plus periodic waterflows may preclude the dynamic of amphibian species and the presence of richer amphibian communities.

\section{Acknowledgement}

The authors thank Marc Grau, Juanjo Francesch, Lluís Serra-Cobo, Antonia Calle and Jordi Serra-Cobo for field assistance. We thank the Parc Natural del Cadí-Moixeró for 
allowing us to conduct this study. Permission for newt capture was granted by the Departament de Medi Ambient de la Generalitat de Catalunya.

\section{REFERENCES}

BARretT, K. (2009). Stream-Breeding Amphibian Responses to Land Use Disturbances. Ph.D. dissertation, Auburn University, Auburn, Alabama, USA.

Barrett, K.; Helms, B.S.; GuYer, C. \& SchoOnOver, J.E. (2010). Linking process to pattern: Causes of stream-breeding amphibian decline in urbanized watersheds. Biological Conservation 143: 1998-2005.

Bates, B.C.; KundzewiCZ, Z.W.; Wu, S. \& Palutikof, J.P. (2008). Climate Change and Water. Series: IPCC Technical Paper, vol. IV. Intergovernmental Panel on Climate Change Secretariat, Geneva, Switzerland.

Baumgartner, N.; WAringer, A. \& WARINGER, J. (1999). Hydraulic microdistribution patterns of larval fire salamanders (Salamandra salamandra salamandra) in the Weidlingbach near Vienna, Austria. Freshwater Biology 41: 31-41.

BeEbeE, T.J.C. \& Griffiths, R.A. (2005). The amphibian decline crisis: A watershed for conservation biology? Biological Conservation 125: 271-285.

Berryman, A.A. (1999). Principles of Population Dynamics and Their Application. Stanley Thornes, Cheltenham, UK.

BIEK, R.; FunK, W.C.; MAXELl, B.A. \& MiLLS, L.S. (2002). What is missing in amphibian decline research: insights from ecological sensitivity analysis. Conservation Biology 16: 728-734.
Bilby, R.E. \& Likens, G.E. (1980). Importance of organic debris dams in the structure and function of stream ecosystems. Ecology 61: 1107-1113.

Blaustein, A.R.; Wake, D.B. \& Sousa, W.P. (1994). Amphibian declines: judging stability, persistence, and susceptibility of populations to local and global extinctions. Conservation Biology 8: 60-71.

Chapman, D.G. (1951). Some properties of the hypergeometric distribution with applications to zoological sample censuses. University of California Publications in Statistics 1: 131-160.

Clergue-Gazeau, M. (1971). L'euprocte pyrénéen. Conséquence de la vie cavernicole sur son développement et sa reproduction. Annales de Spéléologie 26: 825-960.

Clergue-Gazeau， M. \& Martinez-Rica, J.P. (1978). Les différents biotopes de l'urodèle pyrénéen, Euproctus asper. Bulletin de la Société d'Histoire Naturelle de Toulouse 114: 461-471.

Dudgeon, D. (1993). The effects of spateinduced disturbance, predation, and environmental complexity on macroinvertebrates in a tropical stream. Freshwater Biology 30: 189-197.

FunK, W.C.; Donnelly, M.A. \& Lips, K.R. (2005). Alternative views of amphibian toe-clipping. Nature 433: 193.

Houlahan, J.E.; Findlay, C.S.; SchmidT, B.R.; MEYER, A.H. \& KUZMIN, S.L. (2000). Quantitative evidence for global amphibian population declines. Nature 404: 752-755.

JOLLY, G.M. (1965). Explicit estimates from capture-recapture data with both death and immigration-stochastic model. Biometrika 52: 225-247. 
LanCAster, J.; Hildrew, A.G. \& Townsend, C.R. (1990). Stream flow and predation effects on the spatial dynamics of benthic invertebrates. Hydrobiologia 203: 177-190.

Lancaster, J. \& Hildrew, A.G. (1993). Characterizing in-stream flow refugia. Canadian Journal of Fisheries and Aquatic Sciences 50: 1663-1675.

LeIPELT, K.G. (2005). Behavioural differences in response to current: implications for the longitudinal distribution of stream odonates. Archiv für Hydrobiologie 163: 81-100.

MAY, R.M.; CONWAY, G.R.; HASSELl, M.P. \& SouthwOOD, T.R.E. (1974). Time delays, density-dependence and single-species oscillations. Journal of Animal Ecology 43: 747-770.

McCarthy, M.A. \& PARRIS, K.M. (2004). Clarifying the effect of toe clipping on frogs with Bayesian statistics. Journal of Applied Ecology 41: 780-786.

MeYer, A.H.; SCHMidT, B.R. \& Grossenbacher, K. (1998). Analysis of three amphibian populations with quarter-century long time-series. Proceedings of the Royal Society B 265: 523-528.

MONTORI, A. (1988). Estudio Sobre la Biología y Ecología del Tritón Pirenaico Euproctus asper (Dugès 1852) en la Cerdanya. Ph.D. dissertation, University of Barcelona, Barcelona, Spain.

Montori, A. (1991). Alimentación de los adultos de Euproctus asper (Dugès 1852) en la montaña media del prepirineo catalán (España). Revista Española de Herpetología 5: 23-36.

MonTori, A. (1992). Alimentación de las larvas de tritón pirenaico, Euproctus asper, en el prepirineo de la Cerdaña, España. Amphibia-Reptilia 13: 157-167.
Montori, A. (2008). El tritó pirinenc (1a part). El Picot Negre, Revista Informativa del Parc Natural del Cadí Moixeró 11: 9-11.

Montori, A. \& Herrero, P. (2004). Caudata, In M. García-París, A. Montori \& P. Herrero (eds.) Amphibia. Lissamphibia. Series: Fauna Ibérica, vol. 24 (M.A. Ramos, coord.). Museo Nacional de Ciencias Naturales, Madrid, Spain.

Montori, A.; Llorente, G.A. \& RichterBorx, A. (2008). Habitat features affecting the small-scale distribution and longitudinal migration patterns of Calotriton asper in a Pre-Pyrenean population. Amphibia-Reptilia 29: 371-381.

MÜLLER, K. (1954). Investigations on the organic drift in north Swedish streams. Reports of the Institute of Fresh-water Research, Drottningholm 35: 133-148.

PeChManN, J.H.K.; SCOTT, D.E.; Semlitsch, R.D.; Caldwell, J.P.; VitT, L.J. \& GibBons, J.W. (1991). Declining amphibian populations: the problem of separating human impacts from natural fluctuations. Science 253: 892-895.

Petranka, J.W. \& Sin, A. (1986). Environmental instability, competition, and density-dependent regulation of a salamander in streams. Ecology 67: 729-736.

Reed, J.M. \& Blaustein, A.R. (1995). Assessment of "nondeclining" amphibian populations using power analysis. Conservation Biology 9: 1299-1300.

Resh, V.H.; Brown, A.V.; Covich, A.P.; GuRTZ, M.E.; LI, H.W.; MinshaLL, G.W.; Reice, S.R.; Sheldon, A.L.; Wallace, J.B. \& WISSMAR, R.C. (1988). The role of disturbance in stream ecology. North American Benthological Society 7: 433-455. 
Salvidio, S. (2011). Stability and annual return rates in amphibian populations. Amphibia-Reptilia 32: 119-124.

SCHLAEPFER, M.A. (1998). Use of a fluorescent marking technique on small terrestrial anurans. Herpetological Review 29: 25-26.

SEBER, G.A.F. (1965). A note on the multiplerecapture census. Biometrika 52: 249-259.

Sibly, R.M. \& Hone, J. (2002). Population growth rate and its determinants: an overview. Philosophical Transactions of the Royal Society B 357: 1153-1170.

STUART, S.N.; CHANSON, J.S.; COX, N.A.; YounG, B.E.; Rodrigues, A.S.L.; Fischman, D.L. \& WalleR, R.W.
(2004). Status and trends of amphibian declines and extinctions worldwide. Science 306: 1783-1786.

Thiesmeier, B. (1992). Comparative experiments on larval drift of five European urodelan species in a water channel - preliminary results, In Z. Korsós \& I. Kiss (eds.) Proceedings of the Sixth Ordinary General Meeting SEH Budapest 1991. Societas Europaea Herpetologica, Budapest, Hungary, pp. 439-442.

Thiesmeier, B. \& Schuhmacher, $\mathrm{H}$. (1990). Causes of larval drift of the fire salamander, Salamandra salamandra terrestris, and its effects on population dynamics. Oecologia 82: 259-263. 